\title{
Sistem Pakar Metode Forward Chaining Dan Certainty Factor Untuk Mengidentifikasi Penyakit Pertusis Pada Anak
}

\author{
Herman Susilo \\ Stikes Syedza Saintika, Jl. Prof. Hamka No. 228 Air Tawar Timur Padang \\ e-mail : susilo4719@gmail.com
}

\begin{abstract}
One of the diseases belonging to infectious diseases is pertussis disease. This is whooping cough or often also known as the cough of the day that often attacks children. This disease is caused by bacteria Bordetella Pertussis. According to WHO data, this patient ranges from 30 to 50 million cases per year. The impact of this disease can lead to death. To be faster in analyzing these conditions, will enable the technology computer to be detected as early as possible. The purpose of this early detection is to facilitate in finding information, one of the right method is to use forward channeling and certainty factor, in this method is diagnosed based on two factors, namely the key of an expert and user. Expert system that allows to help doctors and patients to know the symptoms of disease in children and the expected solution
\end{abstract}

Keywords: Expert system, pertussis, forward chaining, certainty factor.

\begin{abstract}
Abstrak: Salah satu penyakit yang tergolong kedalam penyakit menular adalah penyakit pertusis. Istilah lain dari penyakit ini adalah batuk rejan atau sering juga dikenal dengan istilah batuk seratus hari yang sering menyerang anak-anak. Penyakit ini diakibatkan oleh bakteri Bordetella Pertusis. Menurut data WHO, penderita penyakit ini berkisar sekitar 30 sampai 50 juta kasus per tahunnya. Dampak akhir dari penyakit ini dapat menyebabkan kematian. Untuk lebih cepat dalam menganalisis penyakit ini diperlukan suatu teknologi komputer agar dapat dideteksi sedini mungkin. Tujuan dari deteksi dini ini adalah agar memudahkan dalam mengidentifikasi penyebarannya, salah satu metode yang tepat adalah menggunakan metode forward chaning dan certainty factor, pada metode ini pengambilan diagnosa berdasarkan dua faktor, perserntase keyanikan dari seorang pakar dan user. Sistem pakar yang dikembangkan diharapkan dapat membantu para doktek dan pasian agar dapat mengetahui gejala penyakit pertusis pada anak serta solusi yang diharapkan
\end{abstract}

Kata kunci: Sistem pakar, pertusis, forward chaining, certainty factor.

\section{PENDAHULUAN}

Menurut data WHO, penderita penyakit pertussis berkisar sekitar 30 sampai 50 juta kasus per tahunnya. Dampak akhir dari penyakit ini dapat menyebabkan kematian. Penyakit Pertusis dapat diderita oleh semua orang tetapi penyakit ini lebih serius bila terjadi pada bayi. Penyakit pertusis terlebih dahulu menyerang saluran pernapasan bagian atas melalui udara ataupun percikan, kuman pathogen dapat mencapai saluran napas bagian bawah ketika sistem pertahanan tubuh menurun (Sumiyati, 2015). Pertusis dalam kondisi berat dapat menyebabkan komplikasi pneumonia, terutama pada anak kurang gizi dan anak dengan gangguan sistem imun (Monita, Yani dan Lestari, 2015). Untuk lebih cepat dalam menganalisis penyakit ini diperlukan suatu teknologi komputer agar dapat dideteksi sedini mungkin. Tujuan dari deteksi dini ini adalah agar memudahkan dalam mengidentifikasi gejala, resiko dan penyebarannya.

Penerapan teknologi informasi dalam pelayanan sistem kesehatan sangat diperlukan (Puspita, Sanjaya dan Ummi, 2015). Begitu juga teknologi informasi pengolahan data penyakit pertusis. Tujuan dari penerapan teknologi informasi ini agar dalam pemberian pelayanan yang lebih cepat, efektif dan efisien. Salah satu metode untuk memberikan penerapan sistem informasi adalah dengan penerapan sistem 
pakar. Hasil sistem pakar nantinya akan dapat memberikan informasi yang benar untuk mendiagnosis secara medis.

Sistem pakar merupakan sebuah aplikasi berbasis komputer yang digunakan untuk menyelesaikan masalah (Mutsaqof, Wiharto dan Suryani, 2015). Sistem Pakar yang baik dirancang agar dapat menyelesaikan suatu permasalahan tertentu dengan meniru kerja dari para ahli, dengan keberadaan Sistem Pakar, orang awam pun dapat menyelesaikan masalah yang cukup rumit yang sebenarnya hanya dapat diselesaikan dengan bantuan para ahli.

Forward Chaining merupakan pencocokan fakta atau pernyataan dimulai dari bagian kiri (IF dulu), dengan kata lain penalaran dimulai dari fakta terlebih dahulu untuk menguji kebenaran hipotesis(Hariyadi, 2016).

Metode Forward Chaining adalah penalaran dari bawah ke atas karena penalaran dari evidence (fakta) pada level bawah menuju konklusi pada level atas di dasarkan pada fakta. Pelacakan ke depan adalah pendekatan yang dimotori data (datadriven), sedangkan Metode Certanty Factor menunjukkan ukuran kepastian terhadap suatu fakta atau aturan. jadi Pelacakan maju ini sangat baik digunakan dalam menidentifikasi penyakit pertusis pada anak serta didukung dengan ukuran kepastian dalam mengidentifikasi penyakit pertusis pada anak yang mana nantinya bisa diakses secara online.

\section{METODE PENELITIAN}

Untuk memberikan panduan dalam penyusunan penelitian ini maka perlu adanya susunan kerangka kerja yang jelas, yang dapat diuraikan sebagai berikut :

1. Mengidentifikasi Masalah

Pada tahap ini penulis melakukan identifikasi terhadap ruang lingkup penelitian yang bertujuan untuk menjaga konsistensi dari penelitian ini sehingga penelitian ini lebih terarah dan tercapainya tujuan dari penelitian yang diharapkan. Ruang lingkup masalah yang akan diteliti harus ditentukan terlebih dahulu, karena tanpa menentukan serta mendefinisikan batasan masalah yang akan diteliti yaitu
Membangun sistem pakar berbasis WEB dengan metode forward chaining dan certanty factor untuk mengidentifikasi penyakit pertusis pada anak, maka tidak akan pernah didapat suatu solusi yang terbaik dari masalah tersebut.

2. Menganalisis Masalah

Analisis masalah bertujuan untuk memahami masalah yang telah ditentukan ruang lingkup atau batasannya. Dari hasil analisis masalah, maka diharapkan Sistem Pakar yang dibangun hendaknya mampu memberikan solusi dalam mengidentifikasi penyakit pertusis pada anak.

3. Menentukan Tujuan

Setelah rumusan permasalahan didapatkan, maka langkah selanjutnya adalah menetapkan tujuan. Manfaat dari menentukan tujuan ini yakni berguna untuk memperjelas kerangka, batasan, ruang lingkup, dan sasaran dari kegiatan penelitian yang ingin dicapai dalam melakukan mengidentifikasi penyakit penyakit pertusis.

4. Mempelajari Literatur

Mempelajari literatur bertujuan untuk lebih mengetahui pengetahuanpengetahuan yang akan diterapkan dalam Sistem Pakar ini. Studi pustaka meliputi, Sistem Pakar, penyakit pertusis, dan metode Forward Chainin, merode Cerainty Factor. Literatur yang akan dipelajari ini ada bersumber dari buku-buku yang berhubungan dengan laporan penelitian, jurnal-jurnal ilmiah yang dipublikasikan di internet, majalah dan surat kabar.

5. Mengumpulkan dan Analisa Data

Pada tahap ini dilakukan pengumpulan data dan informasi untuk lebih mengetahui mengenai sistem yang diteliti.

Berikut bentuk tabel keputusan yang saling keterkaitan dalam setiap atributnya sebagai berikut:

\section{Certainty factor rule.}

Untuk mendapatkan tingkat kepercayaan dapat dengan cara mewawancarai seorang seorang pakar dengan aturan aturan $\mathrm{CF}($ rule), dilihat

\begin{tabular}{lr}
\hline 186 & Fakultas Teknik UMSB \\
& ISSN 2599-2081 \\
& EISSN 2599-2090
\end{tabular}


dari certanity factor dengan berpedoman dari tabel in terpretasi certainty factor. Adapun tabel interprestasi certainty factor dapat dilihat pada tabel 1:

Tabel 1. Certainty Factor Rule

\begin{tabular}{|c|l|c|}
\hline No & Jawaban $($ User $)$ & CF \\
\hline 1 & Tidak Tahu & 0.2 \\
\hline 2 & Mungkin & 0.4 \\
\hline 3 & Kemungkinan Besar & 0.6 \\
\hline 4 & Hampir pasti & 0.8 \\
\hline 5 & Pasti & 1.0 \\
\hline
\end{tabular}

(sibagariang : 2015)

2. Gejala-gejala pada penyakit menular pada penyakit pertusis (batuk rejan) pada anak.

Data gejala ini diperoleh dari lapangan setelah melakukan wawancara dengan seorang pakar, terdapat satu gejala utama dan tiga fase gejala penyakit pertusis pada anak, adapun gejalagejala serta pembobotan setiap gejala dapat dilihat pada tabel 2:

Tabel 2. Gejala Penyakit

\begin{tabular}{|c|c|l|c|}
\hline No & Kode & \multicolumn{1}{|c|}{ Gejala } & $\begin{array}{c}\text { Bobo } \\
\text { t }\end{array}$ \\
\hline 1 & G1 & $\begin{array}{l}\text { Batuk terus } \\
\text { menerus yang } \\
\text { berlangsung 1- } \\
\text { 10 minggu }\end{array}$ & 0.8 \\
\hline 2 & G2 & $\begin{array}{l}\text { Kataralis (1-2 } \\
\text { minggu) batuk } \\
\text { apda mala hari } \\
\text { dan filek }\end{array}$ & 0.8 \\
\hline 3 & G3 & $\begin{array}{l}\text { Spasmodic } \\
\text { (Tegang otot) } \\
\text { 2-4 minggu } \\
\text { dan batuk } \\
\text { semakin keras } \\
\text { diakhiri bunyi } \\
\text { whoop }\end{array}$ & 0.7 \\
\hline 4 & G4 & $\begin{array}{l}\text { Konvacelled } \\
\text { (1-2 minggu) } \\
\text { ditandai } \\
\text { berhentinya } \\
\text { bunyi whoop }\end{array}$ & 0.6 \\
\hline
\end{tabular}

3. Pencegahan penyakit pertusis pada anak

3.1. Pemberian imunisasi DPT pada bayi dan DT pada anak SD.
3.2. Bayi 0-1 tahun diberikan vaksin DPT 3X, mulai umur 2 bulan dan selang minimal 1 bulan

3.3. Diulang pemberian

4. Cara pengobatan Penyakit Pertusis pada anak

Adapun cara pengobatan penyakit pertusis adalah sebagai berikut :
4.1. Diberikan aktibiotik Enitromicin/ penisiln/ azint tronycin

4.2. Diberikan Supourtif untuk mengencer batuk dan oksige $\mathrm{O}_{2}$

\section{Desain Sistem}

Rancangan sistem yang akan dibangun untuk sistem pakar berbasis WEB dengan metode forward chaining dan certanty factor untuk mengidentifikasi penyakit pertusis pada anak yakni :

a.

Perancangan Database

Dalam perancangan database untuk Sistem Pakar ini merupakan alat bantu yang digunakan adalah context diagram, data flow diagram dan juga entity relationship diagram (ERD).

b. Penyusunan Basis Data

Basis data merupakan suatu pengorganisasian sekumpulan data yang saling berhubungan satu dengan lainnya sehingga memudahkan aktifitas untuk memperoleh informasi. Basis data dari sistem merupakan hasil pencatatan input-input yang telah dilakukan. Basis data sistem dapat dibaca dan diisi oleh user dan juga admin pada saat menjalankan sistem. Data penunjang yang didapatkan berupa suatu kesimpulan, fakta-fakta dan aturan yang mengatur proses pencarian data yang saling berhubungan satu sama lain disimpan ke dalam basis data sebagai media penyimpanan.

c. Perancangan Struktur Tabel

Setelah dilakukan perancangan basis data, kemudian dirancanglah struktur tabel yang berguna untuk menentukan entitas-entitas dan atribut-atrubut yang dibutuhkan 
dalam merancang suatu aplikasi Sistem Pakar.

d. Perancangan Interface

Pada tahap ini, program tampilan antarmuka pemakai dirancang dengan menggunakan prinsip mudah digunakan dan mudah dipahami oleh user. Untuk rancangan antarmuka pembuatan program dilakukan dengan menggunakan bahasa pemrograman PHP dan database MySQL, dengan berbasis WEB.

7. Implementasi Sistem

Implementasi sistem menggunakan bahasa pemrograman PHP dan database MySQL. Adapun tujuan dalam implementasi sistem adalah untuk melihat keandalan sebuah sistem, apakah sistem yang kita buat sudah sesuai dengan ketentuan yang telah ada dan sesuai dengan keinginan yang diharapkan.

8. Pengujian Sistem

Pengujian sistem dilakukan untuk memastikan apakah aplikasi Sistem Pakar yang dirancang, sudah mencapai tujuan yang diinginkan dari penelitian. Adapun mekanisme pengujian sistem sebagai berikut :

a. Pengujian sistem dilakukan dengan menggunakan bahasa pemrograman PHP dan database MySQL dengan berbasis WEB.

b. Data yang digunakan dalam pengujian hasil adalah penyakit pertusis.

c. Kriteria dalam menentukan keberhasilan pengujian sistem adalah hasil yang dikeluarkan sistem sesuai dengan penyakit pertusis yang akan diidentifikasi

\section{Analisa Hasil}

Pada tahap ini adalah kelanjutan dari pengujian sistem, tujuan analisa hasil adalah melihat sejauhmana fungsi sistem yang telah dirancang bekerja pada responden.

\section{HASIL DAN PEMBAHASAN}

A. Analisa inferensi Forward Chaining Proses identifikasi dilakukan saat gejala yang diinputkan sesuai dengan rule dan aturan yang telah ditetapkan kemudian dari proses rule tersebut akan ditemukan hasil identifikasi berupa penyakit pertusis pada anak. Berikut algoritma secara umum dalam mengidentifikasi penyakit pertusis berdasarkan aturan Forward Chaining.

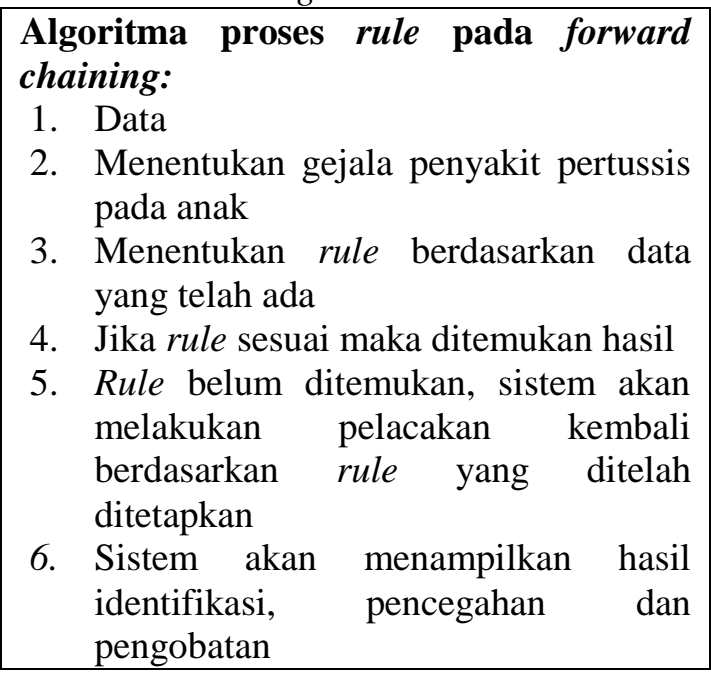

Pada tahapan selanjutnya untuk proses forward chaining pada sistem pakar penyakit pertusis pada anak, akan dilakukan alur proses kerja yang akan digambarkan dalam bentuk flowchart

Untuk lebih jelasnya tentang implementasi forward chaining metode forward chaining dapat dijelaskan sebagai berikut :

1. Menentukan gejala penyakit pertusis pada anak.

Berdasarkan hasil wawancara dengan seorang pakar terdapat 4 gejala pada penyakit pertusis sesuai dengan yang terdapat pada tabel 4.2 yang ditadai dengan kode G1, G2, G3 dan G4, data gejala tersebut akan diinputkan kedalam sistem.

2. Menentukan rule berdasarkan data yang diperoleh

Pada penyajian fakta berdasarkan representasi pengetahuan yang sudah dijelaskan di atas, untuk perencanaan identifikasi penyakit pertusis, maka disusun daftar aturan (rule) yang sesuai dengan prosedur yang telah ditentukan, untuk lebih jelasnya dapat seperti berikut :

$\begin{array}{lr}188 & \text { Fakultas Teknik UMSB } \\ & \text { ISSN 2599-2081 } \\ & \text { EISSN 2599-2090 }\end{array}$


IF Batuk terus menerus yang berlangsung 1-10 minggu True

AND Kataralis (1-2 minggu) batuk apda mala hari dan filek True

AND Spasmodic (Tegang otot) 2-4 minggu dan batuk semakin keras diakhiri bunyi whoop True

AND Konvacelled (1-2 minggu) ditandai berhentinya bunyi whoop True THEN Penyakit Pertusis

3. Jika rule ditemukan maka akan ditemukan hasil

Pada tahap ini jika rule ditemukan akan menghasilkan tampilan berupa jenis penyakit berdasarkan terhadap gejala yang telah diinputkan.

a. Basis pengetahuan dari jenis penyakit serta kode penyakit, dapat dijelaskan sebagai berikut:

Kode Penyakit : P001 = Penyakit Pertusis (batuk Rejan)

b. Basis pengetahuan dari cara pengobatan serta kode pengobatan dapat dilihat pada tabel berikut :

Tabel 3. Jenis penyakit, pencegahan dan pengobatan

\begin{tabular}{|c|c|}
\hline $\begin{array}{c}\text { Penyaki } \\
\text { t } \\
\text { pertusis }\end{array}$ & Keterangan \\
\hline $\begin{array}{c}\text { Pencega } \\
\text { han }\end{array}$ & $\begin{array}{l}\text { a. Pemberian imunisasi DPT pada } \\
\text { bayi dan DT pada anak SD } \\
\text { b. Bayi 0-1 tahun vaksin DPT } \\
3 \mathrm{X} \text {, mulai umur } 2 \text { bulan dan } \\
\text { selang mininal satu bulan } \\
\text { c. Diulang pemberian }\end{array}$ \\
\hline $\begin{array}{c}\text { Pengoba } \\
\tan \end{array}$ & \begin{tabular}{llr} 
a. & $\begin{array}{l}\text { Pembereian } \\
\text { enitromisin/ }\end{array}$ & \multicolumn{2}{c}{ antibiotik } \\
tronycin & & \\
b. & $\begin{array}{l}\text { Pemberian } \\
\text { (pengencer }\end{array}$ & batuk), \\
Oksigen $\left(\mathrm{O}_{2}\right)$ & & dan
\end{tabular} \\
\hline
\end{tabular}

4. Jika rule tidak ditemukan sistem akan melakukan pelacakan kembali berdasarkan aturan/ rule yang ditetapkan.

5. Sistem akan menghasilkan identifikasi penyakit pertusis
Berdasarkan data gejala dan data penyakit yang ada didalam sistem, maka hasil yang akan ditampilkan didalam sistem tersebut.

\section{B. Pengujian}

Metode Certainty Factor (Faktor Kepastian) diperkenalkan oleh Shortliffe Buchanan dalam pembuatan MYCIN. Certainty Factor adalah nilai parameter klinis yang diberikan MYCIN untuk menunjukan besar kepercayaan. Rumus dasar factor kepastian (Sibagarian, 2015), Certainty Factor memperkenalkan konsep keyakinan dan ketidakyakinan yang diformulasikan dalam rumus dasar sebagai berikut :

$\mathrm{CF}[\mathrm{H}, \mathrm{E}]=\mathrm{MB}[\mathrm{H}, \mathrm{E}]-\mathrm{MD}[\mathrm{H}, 3] \ldots . .(1)$

$$
\begin{aligned}
& \mathrm{CF}[\mathrm{H}, \mathrm{E}]=\text { Faktor Kepastian } \\
& \mathrm{MB}[\mathrm{H}, \mathrm{E}] \quad=\text { Ukuran kepercayaan } \\
& \text { terhadap hipotesis } \mathrm{H} \text {, jika } \\
& \text { diberikan evidence } \mathrm{E} \\
& \text { (antara } 0 \text { dan 1) } \\
& \mathrm{MD}[\mathrm{H}, \mathrm{E}] \quad=\text { Ukuran ketidakpercayaan } \\
& \text { terhadap hipotesa } \mathrm{H} \text {, jika } \\
& \text { diberikan Evidence e } \\
& \text { (antara } 0 \text { dan 1) } \\
& \mathrm{E} \quad=\text { Evidence (peristiwa atau } \\
& \text { fakta) } \\
& \mathrm{H} \quad=\text { Hipotesa (dugaan) }
\end{aligned}
$$

\subsubsection{Algoritma Proses Certainty} Factor

1. Data

2. Inisialisasi gejala-gejala penyakit pertusis pada anak

3. Tampilkan gejala penyakit pertusis dan nilai Certainty factor $(C F)$

4. Proses gejala penyakit pertusis pada anak

5. CF kombinasi penyakit pertusis pada anak

6. Hasil nilai kombinasi $\mathrm{CF}$ (CF Combine)

Algoritma Certainty Factor akan dijelaskan sebagai berikut :

Analisa Data

1. Data 
2. Inisialisasi gejala-gejala penyakit menular pada balita

\section{Pertanyaan yang dipilih user :}

1. Batuk terus menerus yang berlangsung 1-10 minggu

2. Kataralis (1-2 minggu) batuk apda mala hari dan filek

3. Spasmodic (Tegang otot) 2-4 minggu dan batuk semakin keras diakhiri bunyi whoop

4. Konvacelled (1-2 minggu) ditandai berhentinya bunyi whoop

5. Tampilkan Kategori penyakit $\mathrm{CF}$ Pakar dan CF User

Tabel 4. Kategori CF Pakar

\begin{tabular}{|c|c|}
\hline Pertayaan & $\begin{array}{l}\text { Nilai } \\
\text { CF } \\
\text { Pakar }\end{array}$ \\
\hline $\begin{array}{l}\text { 1. Batuk terus menerus yang } \\
\text { berlangsung 1-10 minggu }\end{array}$ & 0.8 \\
\hline $\begin{array}{l}\text { 2. Kataralis (1-2 minggu) } \\
\text { batuk apda mala hari dan } \\
\text { filek }\end{array}$ & 0.8 \\
\hline $\begin{array}{l}\text { 3. Spasmodic (Tegang otot) } \\
2-4 \text { minggu dan batuk } \\
\text { semakin keras diakhiri } \\
\text { bunyi whoop }\end{array}$ & 0.7 \\
\hline $\begin{array}{l}\text { 4. Konvacelled (1-2 } \\
\text { minggu) ditandai } \\
\text { berhentinya bunyi whoop }\end{array}$ & 0.6 \\
\hline
\end{tabular}

Tabel 5. Nilai CF user

\begin{tabular}{|l|l|c|}
\hline Jawaban User & Kode & Bobot \\
\hline Tidak & CF1 & 0.0 \\
Mungkin & CF2 & 0.4 \\
Kemungkinan & CF3 & 0.6 \\
Besar & & \\
Hampir Pasti & CF4 & 0.8 \\
Pasti & CF5 & 1.0 \\
\hline
\end{tabular}

3. Proses kondisi penyakit pertusis pada anak

Proses Hasil :

$\mathrm{CF}[\mathrm{H}, \mathrm{E}]=\mathrm{CF}[\mathrm{H}] \times \mathrm{CF}[\mathrm{E}]$..(2)

- CF Gejala 1 :

$$
\begin{aligned}
& \mathrm{CF}[\mathrm{H}, \mathrm{E}]=\mathrm{CF}[\text { pakar }] * \mathrm{CF}[\text { user }] \\
& =0.8 * 1.0 \\
& =0.8
\end{aligned}
$$

- CF Gejala 2 :

$$
\begin{aligned}
& \mathrm{CF}[\mathrm{H}, \mathrm{E}]=\mathrm{CF}[\text { pakar }] * \mathrm{CF}[\text { user }] \\
& =0.8 * 0.8 \\
& =0.64
\end{aligned}
$$

- CF Gejala 3 :

$$
\mathrm{CF}[\mathrm{H}, \mathrm{E}]=\mathrm{CF}[\text { pakar }] * \mathrm{CF}[\text { user }]
$$$$
=0.7 * 0.6
$$$$
=0.42
$$

- CF Gejala 4 :

$\mathrm{CF}[\mathrm{H}, \mathrm{E}]=\mathrm{CF}[$ pakar $] * \mathrm{CF}[$ user $]$

$=0.6^{*} 0.4$

$=0.24$

4. CF kombinasi penyakit pertusis pada anak

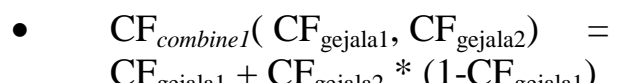

$\begin{array}{ll}\frac{\text { Jawaban User }}{\text { Tidak Tahu }} & \text { Kode } \\ \text { Mungkin } & \text { CF1 } \\ \text { Kemungkinan Besar } & \text { CF2 } \\ \text { Hampir Pasti } & \text { CF4 } \\ \text { Pasti } & \text { CF5 }\end{array}$

Kode

$\mathrm{CF} 2$

$\mathrm{CF} 3$

CF5

$$
\begin{aligned}
& \begin{array}{c}
=0.8+0.64 \\
\mathrm{CF}_{\text {old1 } 1}=\mathbf{0 . 9 2 8} \\
\mathrm{CF}_{\text {combine2 } 2}\left(\mathrm{CF}_{\text {old1 } 1}, \mathrm{CF}_{\text {gelala3 }}\right) \\
\mathrm{CF}_{\text {old1 } 1}+\mathrm{CF}_{\text {gejala3 } 3} *\left(1-\mathrm{CF}_{\text {old1 } 1}\right)
\end{array} \\
& =0.928+0.42 \\
& \mathrm{CF}_{\text {old2 }}=\mathbf{0 . 9 5 8 2 4} \\
& \text { - } \mathrm{CF}_{\text {combine3 }}\left(\mathrm{CF}_{\text {old2 } 2}, \mathrm{CF}_{\text {gejala4 }}\right)= \\
& \mathrm{CF}_{\text {old2 }}+\mathrm{CF}_{\text {gejala } 4}\left(1-\mathrm{CF}_{\text {old } 2}\right) \\
& =0.95824+0.24 \\
& \mathrm{CF}_{\text {old3 }}=\mathbf{0 . 9 7}
\end{aligned}
$$

$\mathrm{CF}_{\text {old3 }}$ merupakan $\mathrm{CF}$ penyakit, berdasarkan hasil perhitungan $\mathrm{CF}$ diatas, maka nilai CF penyakit 0.97 .

5. Hasil Nilai Kombinasi Nilai CF

Setelah didapat didapat nilai $\mathrm{CF}$ penyakit selanjutnya menghitung persentase keyakinan terhadap penyakit dengan persamaan :

$$
\begin{aligned}
\text { Persentase } & =\text { CF penyakit } * 100 \\
& =0.97 * 100 \\
& =97 \%
\end{aligned}
$$

6. Hasil tingkat keyakinan CF Penyakit Untuk melihat tingkat keyakinan dari perhitungan nilai $\mathrm{CF}$ penyakit dapat dilihat dari ketentuan berikut :

1. Jika nilai $\mathrm{CF}$ penyait $>=0$ dan $<=0.35$ : Tidak Tahu;

2. Jika nilai $\mathrm{CF}>0.35$ dan $<=0.55$ : Mungkin 
3. Jika nilai $\mathrm{CF}>0.55$ dan $<=0.75$ : Kemungkinan Besar

4. Jlka nilai $\mathrm{CF}>0.75$ dan $<=0.95$ : Hampir Pasti

5. JIka nilai $\mathrm{CF}>0.95$ dan $<=1.0$ : Pasti Berdasarkan berdasarkan ketentuan diatas dan jika dibandingkan dengan nilai $\mathrm{CF}$ penyakit $=0.97$, maka tingkat keyakinan berdasarkan ketentusn adalah

\section{PASTI.}

\section{Implementasi System}

Setelah melakukan analisa sistem pada proses perancangan Sistem pakar penyakit petusis pada anak tahapan selanjutnya implementasi sistem pakar. Pada tahap implementasi sistem pakar ini dijelaskan bagaimana langkah-langkah pengoperasian sistem pakar dalam melakukan indentifikasi penyakit pertusis pada anak. Implementasi serta pengujian sistem ini menggunakan bahasa pemrograman PHP (Hypertext Preprocessor) yang berbasis website. Berikut ini adalah tampilan halaman dari sistem pakar penyakit menular pada balita yang telah dibuat.

\section{Halaman Login}

Halaman login adalah halam awal dari sistem pakar ini, dimana user diminta untuk menginutkan username dan password yang valid, jika proses validasi sesuai user akan menuju halam home. Tampilan halaman login dapat dilihat pada gambar berikut :

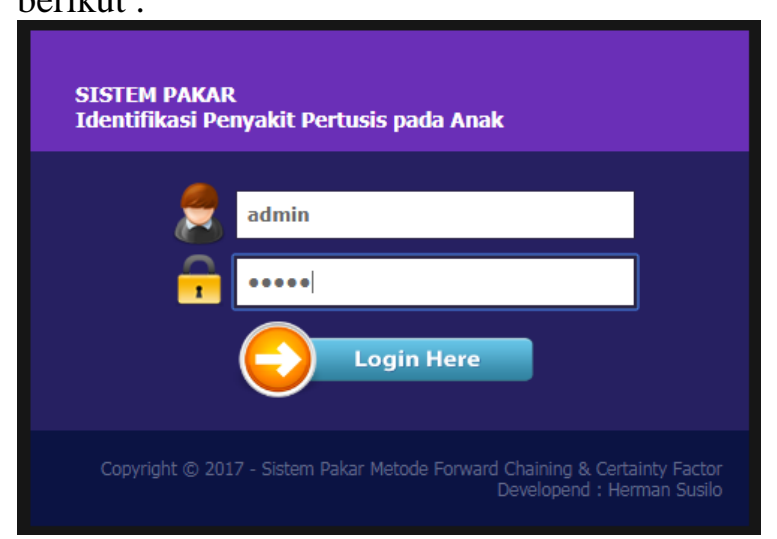

Gambar. 1. Fom Login

\section{Halaman home}

Halaman home adalah halaman setelah proses login selesai, halaman home ini terdapat beberapa menu, yaitu input data user, input data penyakit, input data gejala, indentifikasi penyakit dan logout, adapun tampilan halam home dapat dilihat pada gambar berikut :

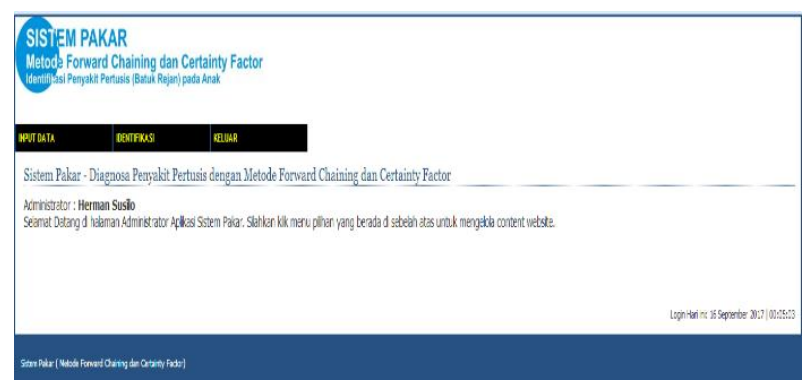

Gambar. 2 Halaman Home

\section{Halaman data user}

Pada halaman ini aplikasi akan menampilkan semua data user dari pengguna sistem, yang mana dari ini yang nantinya digunaka untuk proses login ke sistem, adapun tampilan dari data user dapat dilihat pada gambar berikut :

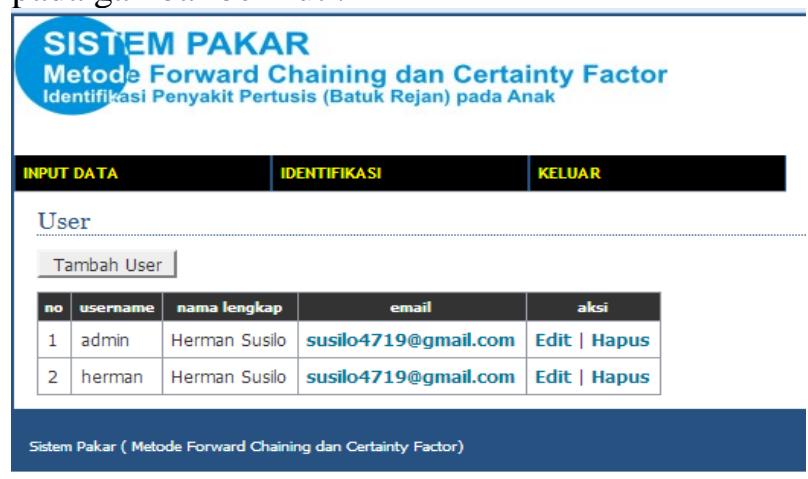

\section{Gambar. 3 fom data user}

\section{Halamn data penyakit}

Halaman ini menampung semua data penyakit, penyebab, pencegahan dan pengobatan penyakit pertusis yang telah diinputkan user kedalam sistem, adapun tampilan halaman data penyakit dapat dillihat pada gambar berikut :

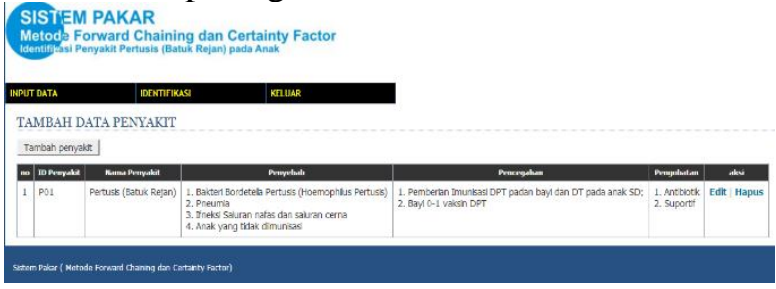

Gambar. 4 Fom data penyakit 
Jika ingin menambahkan data penyakit baru, sistem telah menyediakan tombol Tambah penyakit yang berfungsi untuk menambahkan data penyakit baru, adapun tampilan tambah data penyakit dapat dilihat dari gambar berikkut :

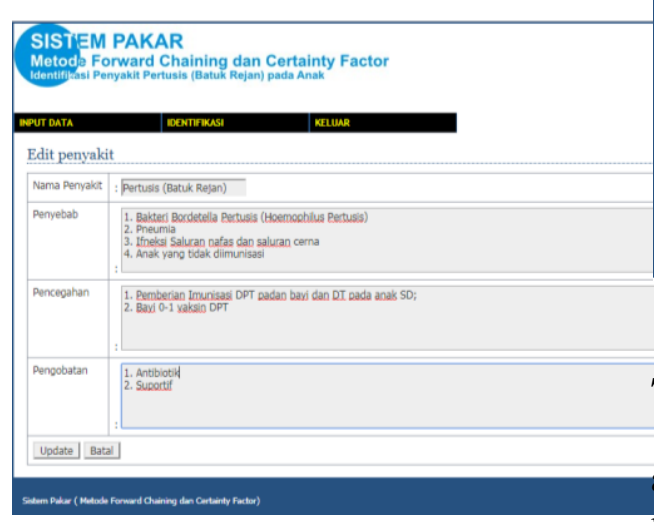

\section{Gambar. 5 Form tambah data penyakit}

\section{Halaman data gejala}

Halaman data gejala berfungi menampilkan semua data gejala yang terkait dengan penyakit pertusis, dimana input data gejala dilengkapi dengan nilai Certainty Factor pakar, adapun tampilan data gejala dapat dilihat dari gambar berikut :

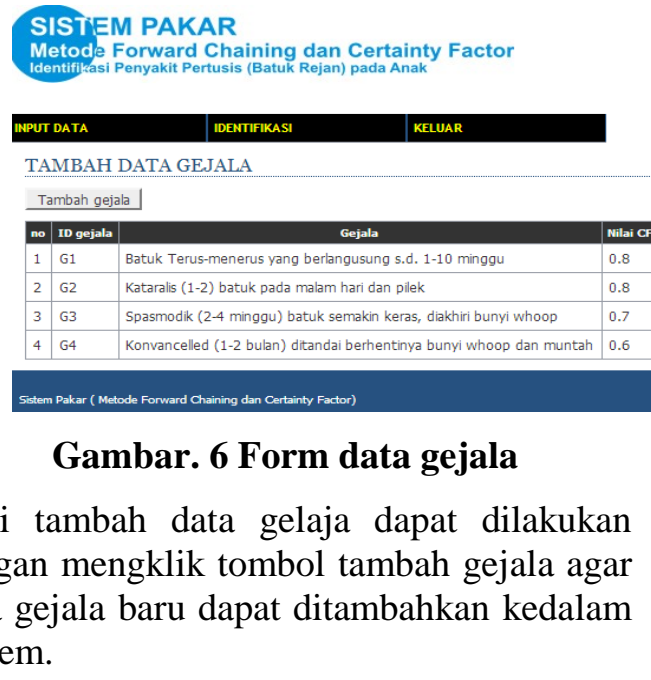

\section{Form Identifikasi}

Halaman ini berisikan daftar gejalagejala penyakit pertusis sejumlah empat gejala yang timbul pada balita, usr akan memilih semua gejala berdasarkan gejalagejala yang tampak pada anak, kemudian user diminta untuk menjawab tingkat keyakinan yang terkait dengan gejala yang timbul pada anak, adapun tampilan halaman identifikasi penyakit dapat dilihat pada gambar berikut :
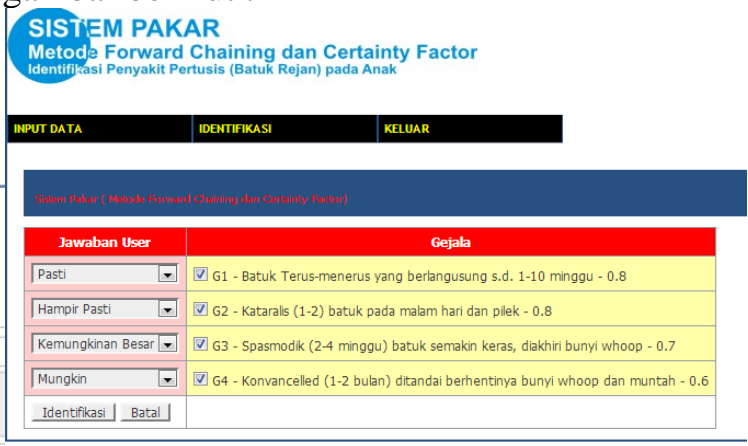

Gambar. 7 form identifikasi penyakit

\section{Form Hasil Proses Identifikasi}

Hasil proses identifikasi didapat abila user telah memilih semua gejala dan menjawab nilai keyakinan sesuai gejala yang ada bayi anak, adapun tampilan porses hasil identifikasi pada sistem ini dapat dilihat pada gambarberikut.

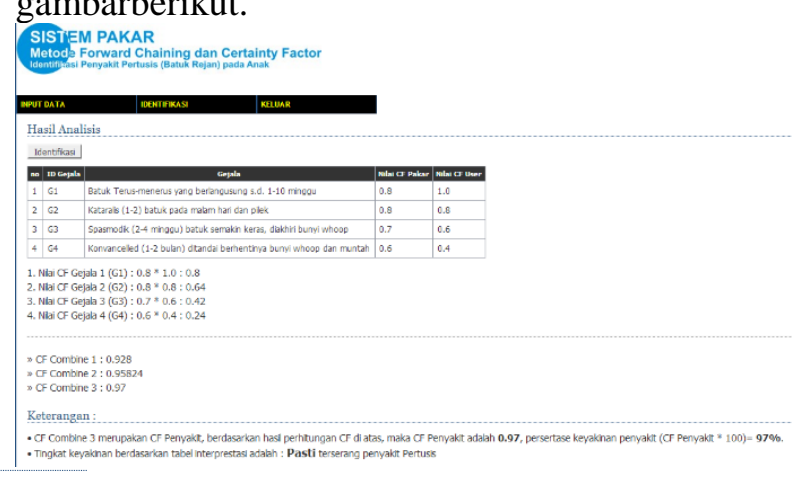

Gambar. 8 Form hasil identifikasi penyakit

\section{STMPULAN}

Kesimpulan dapat diambil dari penjelasan dan hasil penelitian yang sudah dilakukan implementasi dan evaluasi di atas, maka dapat diperoleh kesimpulan sebagai berikut:

1. Hasil pengujian dengan menggunakan metode Forward Chaining dan certainty factor, didapatkan nilai tingkat keyakinan penyakit pertusis pada anak $97 \%$.

2. Penerapan sistem pakar diagnosa penyakit pertusis pada anak dapat

192 Fakultas Teknik UMSB $\quad$ ISSN 2599-2081


membantu user dalam penggunaan dan melakukan proses identifikasi penakit pertusis.

3. Metode forward chaining pada sistem pakar yang telah dibangun dapat memberikan hasil optimal kepada pengguna dalam pengambilan suatu keputusan berdasarkan output ditampilkan sistem.

\section{UCAPAN TERIMA KASIH}

Terimakasih kepada Stikes Syedza Saintika yang telah memberikan dorongan dan masukan dalam penulisan penelitian ini, serta kepada UPI YPTK Padang yang telah banyak memberikan masukan dan bimbingan dalam penulisan ini.

\section{DAFTAR PUSTAKA}

Ghozali. M.F, Eviyanti. A. Sistem Pakar Dini Penyakit Leukemia dengan Metode Certanty Factor. Kineka. 2016; Vol.1 No. 3. Halaman : 135146.

Halim.S, Hansun. S. Penerapan Metode Certainty Factor dalam Sistem Pakar Pendeteksi Resiko Osteoporosis dan Osteoarthritis. ULTIMA Computing. 2015; Vol. VII, No. 2. Halaman : 59-69

Hariyadi, M. K. (2016). Pengembangan Sistem Pakar Berbasis Aturan Untuk Menentukan Mata Kuliah Yang Akan Diambil Ulang (Remedial) Dengan Metode Forward Chaining. Menara Ilmu, X(64), 62-74. Retrieved from http://joernal.umsb.ac.id/index.php/me narailmu/article/view/96

Monita. O, Yani. F.F, Lestari.Y. Profil Pasien Pneumonia Komunitas di Bagian Anak RSUP DR. M. Djamil Padang Sumatera Barat. Jurnal Kesehatan Andalas. 2015; 4(1) : halaman : 218-226

Mutsaqof.A.A.N, Wiharto ,Suryani.E. Sistem Pakar Untuk Mendiagnosis Penyakit Infeksi Menggunakan Forward Chaining. Jurnal ITSMART.2015. Vol 4. No 1. Halman : 43-47
Puspita. K, Sanjaya. A, Ummi. K. Sistem Pakar Penelusuran Bakteri Chlamydia Trachomatis Menggunakan Forward Chaining. CSRID Journal. 2015; Vol.7 No.2. Halaman. 124-134

Ramdhani. A, Isnanto. R, Windasar. I.P. Pengembangan Sistem Pakar Untuk Diagnosis Penyakit Hepatitis Berbasis Web Menggunakan Metode Certainty Factor. Jurnal Teknologi dan Sistem Komputer. 2015; Vol.3, No.1. Halaman : 58-64.

Sumiyati. Hubungan Jenis Kelamin Dan Status Imunisasi Dpt Denganpneumonia Pada Bayi Usia 0-12 Bulan, Jurnal Kesehatan Metro Sai Wawai. 2015; Volume VIII No.2. Halaman : 63-69

Sunarya. I.M.G, Wirawan. I.M.A, Sukendry.N.M.N. Sistem Pakar Pendeteksi Gizi Balita dan Alternatif Pencegahan Menggunakan Metode Certainty Factor. Jurnal Nasional Pendidikan Teknik Informatika.2017; Volume 6, Nomor 1. Halaman : 50-59

Saputra. D, Lestari.U, Sutanta. E. Sistem Pakar Untuk Diagnosa Penyakit Kucing Berbasis Web Menggunakan Frameworkcodeigniter Web Based Expert System For Diagnosing Cat Disease Using Codeigniter Framework. Jurnal SCRIPT.2015; Vol. 3 No. 1. Halaman : 29-38.

Suparth. I.K.D.G, Sari.I.N. Sistem Pakar Diagnosa Awal Penyakit Kulit Pada Sapi Bali dengan Menggunakan MetodeForward chaining dan Certainty Factor. Jurnal Nasional Pendidikan Teknik Informatika.2014; Volume 3, Nomor 3. Halaman : 110-117.

Sibagariang. B. Sistem Pakar Diagnosa Penyakit Sapi dengan Metode Certainty Factor Berbasis Android. Jurnal TIMES. 2015; Vol.IV. Nomor : 2. Halaman : 35-39

Verina. W. Penerapan Metode Forward Chaining untuk Mendeteksi Penyakit THT. Jatisi. 2015; Vol. 1 No. 2. Halaman : 123-128. 
Wijaya. E. Analisis Penggunaan Algoritma

Breadth First Search Dalam Konsep

Artificial Intellegencia. Jurnal

TIME.2013; Vol. II No 2.

Halaman : 18-26 